\title{
Efektifitas Model Pembelajaran Problem Based Learning dalam Penguatan Karakter KI 2 Melalui Pengembangan Perangkat Pembelajaran di SDK Sang Timur Kabupaten Sumenep
}

\author{
Fajar Budiyono $^{1}$, Framz Hardiansyah ${ }^{2}$ \\ fajarbudiyono@ stkippgrisumenep ${ }^{1,}$ framz@ stkippgrisumenep.ac.id $^{2}$ \\ PGSD, STKIP PGRI Sumenep ${ }^{1}$ \\ PGSD, STKIP PGRI Sumenep ${ }^{2}$
}

\begin{abstract}
Abstrak: Penelitian ini bertujuan untuk menghasilkan perangkat pembelajaran dengan model problem based learning yang layak, praktis, dan efektif untuk melakukan penguatan karakter pada KI 2. Perangkat pembelajaran tersebut diujikan terhadap siswa kelas IV di SDK Sang Timur tahun pelajaran 2020/2021. Penelitian ini merupakan penelitian pengembangan, dengan model 4-D. Rancangan ujicoba perangkat menggunakan one group pretest-posttest design. Subjek penelitian ini adalah siswa Kelas IV. Subjek penelitian ini berjumlah 13 siswa. Hasil penelitian menunjukkan: (1) validitas perangkat pembelajaran berkategori baik dengan rata-rata nilai 3.7; tingkat keterbacaan lembar kegiatan siswa berkategori baik dan memperoleh rata-rata nilai 3.6; (2) keterlaksanaan RPP berkategori baik; aktivitas siswa menunjukkan pada penguatan karakter KI 2 dengan perolehan $86.56 \%$ pada pertemuan 1 dan $90.62 \%$ pada pertemuan 2; (3) siswa memberikan nilai postif terhadap penguatan karakter utama dengan ratarata nilai $89.25 \%$ melalui jurnal sikap . Berdasarkan hasil dan diskusi penelitian, dapat disimpulkan bahwa perangkat pembelajaran dengan model problem based learning dalam melakukan penguatan karakter terhadap pembelajaran PPKn layak, praktis, dan efektif digunakan dalam proses pembelajaran.
\end{abstract}

Kata kunci: Pemecahan masalah, penguatan karakter, perangkat pembelajaran

\section{The effectiveness of Problem Based Learning in KI 2 Characters Strengthening through learning tools development at SDK Sang Timur, Sumenep}

\begin{abstract}
This Research aims to produce the validity, practically, and effectiveness learning tools through problem based learning in chracters' reinforcement toward civics. The learning materials were tried out to the fourth grade at SDK Sang Timur Sumenep in the first semester of the academic year 2020/2021. his research is the development research, with four D models. The research subject is fourth grade and the number of students are 12 students. The trial design used one-group pretest-posttest design. The results were obtained: (1) the validity of learning materials were good category. The
\end{abstract}


Fajar, Framz, Efektifitas Model Pembelajaran PBL

result indicated 3.7 points; and the worksheets got good category. The result indicated 3.6 points (2) learning performance was good category; student's activities were focused to character indicator in KI 2 and got $86.56 \%$ in first meeting and $90.62 \%$ in second meeting; (3)students gave the positive result to main characters in KI2 with $89.25 \%$ by attitude sheets . Based on the result and discussion of this research, it can be concluded that the problem based learning in chracters' reinforcement toward civics were feasible, practical, and effective to be used at learning process.

Keywords: Problem Based Learning, characters strengthening, learning tools.

\section{PENDAHULUAN}

Memasuki tatanan kehidupan baru, semua mengalami dampak perubahan yang sangat signifikan terlebih di bidang pendidikan. Saat ini arah pendidikan harus terbiasa dengan tatanan kehidupan baru. Dimana siswa diarahkan agar bisa belajar secara mandiri. Hal yang dibutuhkan dalam pembelajaran saat ini tidak harus menuntaskan kurikulum melainkan bagaimana pembelajaran harus lebih kontekstual sesuai dengan kondisi yang ada. Oleh sebab itu, sangat tidak efektif jika guru hanya mengandalkan metode ceramah saja. Apalagi jam pembelajaran tatap muka secara langsung di tatanan kehidupan baru dipangkas demi menjaga kesehatan bersama. Selain itu, arah pembelajaran saat ini tidak hanya menekan pada aspek kognitif saja.

Sebagai seorang guru fokus pembelajaran saat ini juga harus mengutamakan penguatan karakter agar siswa tidak menyerah dengan kondisi saat ini. Salah satu model pembelajaran yang sesuai dalam penguatan karakter adalah menggunakan model pembelajaran problem based learning. Sesuai dengan namanya, pembelajaran berbasis masalah adalah model pembelajaran yang menitikberatkan pada masalah-masalah yang dihadapi siswa terkait dengan KD yang sedang dipelajari siswa. Masalah yang dimaksud bersifat nyata atau sesuatu yang menjadi pertanyaan-pertanyaan pelik bagi siswa. PBL berusaha membantu siswa agar menjadi pebelajar yang mandiri dan otonom. Melalui bimbingan guru yang dilakukan secara berulang-ulang mendorong dan mengarahkan siswa untuk mengajukan pertanyaan, mencari penyelesaian terhadap masalah nyata dan siswa belajar untuk menyelesaikan tugas-tugas tersebut secara mandiri dalam hidupnya kelak. Menurut Retman dalam (Winataputra, 2011) mengemukakan bahwa kegiatan pembelajaran terletak dalam mengemukakan masalah yang dihadapi dalam kehidupan keseharian karena dengan permasalahan tersebut siswa akan dimotivasi untuk menggunakan pikirannya secara kreatif dan belajar secara intensif. Tidak hanya itu, PBL is a student-centered pedagogy in which students learn both thinking strategies and domain knowledge through problem solving (Wallden \& Makinen, 2013). Melalui kegiatan pembelajaran masalah ini, peserta didik dihadapkan pada permasalahan yang harus dipecahkan. Hal tersebut sejalan dengan hasil penelitian yang dilaksanakan oleh (Soraya, Jampel, \& Diputra, 2018) menyatakan model problem 
Fajar, Framz, Efektifitas Model Pembelajaran PBL

based learning berbasis kearifan lokal berpengaruh positif terhadap sikap sosial dan berpikir kritis.

Secara esensi pembelajaran berbasis masalah merupakan pembelajaran yang mengarahkan siswa untuk termotivasi dalam pembelajaran baik itu secara mandiri atau berkelompok (Hamburg \& Vladut, 2016). Motivasi adalah bagian dari butir sikap karakter utama mandiri. Di dalam pembelajaran, penanaman karakter sangat diutamakan terlebih lima karakter utama yang telah dijelaskan dalam perundangundangan yaitu: religiusitas, nasionalisme, gotong royong, mandiri dan integritas. Sesungguhnya penguatan karakter merupakan jembatan awal dalam mempersiapkan daya saing siswa untuk mempunyai kompetensi yang dibutuhkan di abad 21. Selain itu, Problem based learning (PBL) merupakan model pembelajaran yang memiliki ciri khas yaitu selalu dimulai dan berpusat pada masalah (Fatimah, 2012).

Pembelajaran pemecahan masalah dipandang penting agar siswa memiliki keterampilan dalam menghadapi dan mengatasi masalah. Berbagai penelitian telah diadakan oleh para ahli mengenai pemecahan masalah sebagai suatu proses kreatif. Menurut hasi penelitian yang diaksanakan oleh (Budiarti \& Airlanda, 2019) menunjukkan adanya peningkatan keterampilan berpikiri kritis yang ditunjukkan dengan data pada pra siklus sebesar $41 \%$, pada siklus satu meningkat menjadi $68,81 \%$ dan pada siklus dua meningkat menjadi $81.81 \%$. Tidak hanya itu, hasil penelitian (Prasasti, 2015) menunjukkan bahwa efektifitas problem based learning disertai FD menunjukkan peningkatan dengan kategori tinggi dalam memberdayakan kemampuan menganlisis. Dengan begitu dapat disimpulkan, model pembelajaran problem based learning dapat meningkatkan kemampuan siswa dalam menganalisis sehingga siswa dengan mudah mencari solusi permasalahan apa yang dihadapi.

Selanjutnya, Menurut Osborn dalam (Tilaar, 2012) telah mendefinisikan untuk pertama kalinya mengenai pemecahan masalah secara kreatif yang meliputi tiga tingkat: 1) Menemukan fakta yang mengidentifikasikan masalah dan mengumpulkan faktafakta, 2) Menemukan ide pemecahan masalah, 3) Menemukan solusi termasuk evaluasi dan implementasi ide. Oleh sebab itu, melalui kegiatan pembelajaran pemecahan masalah ini siswa dihadapkan pada pemecahan masalah yang harus dipecahkan, baik secara individu maupun secara kelompok. Pemecahan yang dilakukan secara individual akan mendorong siswa untuk berpikir kreatif. Apabila dilakukan secara kelompok akan mendorong siswa untuk bekerjasama sehingga kegiatan pembelajaran berlangsung efektif dan efisien.

Pembelajaran berbasis masalah ini tidak dirancang untuk membantu guru untuk menyampaikan sejumlah informasi kepada siswa. Akan tetapi pembelajaran berdasarkan masalah ini diefektifkan terutama untuk membantu siswa dalam pemecahan masalah. Pernyataan tersebut diperkuat dengan hasil penelitian yang dilakukan oleh (Sumartini, 2016) di mana pembelajaran berbasis masalah menjadi pembelajaran yang lebih baik daripada pembelajaran konvensional. Dengan begitu, implementasi dari pembelajaran berbasis masalah secara khusus adalah untuk mendorong berpikir tingkat 
Fajar, Framz, Efektifitas Model Pembelajaran PBL

tinggi siswa dalam situasi yang berorientasi pada masalah dunia nyata yang kemudian dilakukan pemecahan dari masalah yang dihadapi secara mandiri.

Selain itu pembelajaran berbasis masalah dirancang tidak hanya untuk meningkatkan kemampuan kognitif saja, melainkan melalui masalah yang dihadapi siswa mampu membangun penguatan karakter. Di dalam kurikulum 2013 penguatan karakter memang sudah terintegrasi dengan tema dalam semua mata pelajaran. Namun, materi untuk penguatan karakter hanya terfokus pada mata pelajaran agama dan PPKn. Di Sekolah Dasar, mata pelajaran PPKn adalah pelajaran yang wajib diajarkan kepada siswa. Apalagi muatan materi pelajaran PPKn mencakup fondasi utama dalam menjaga keutuhan Negara. Saat ini arah pembelajaran PPKn merujuk pada empat pilar Negara yaitu, Pancasila, UUD 1945, NKRI dan Bhineka Tunggal Ika. Hal tersebut sependapat dengan (Wahana \& Mayasari, 2017) menyatakan tujuan mata pelajaran PPKn mewujudkan nilai-nilai Pancasila untuk membentuk kepribadian yang teladan dan berguna bagi masyarakat dan Bangsa sesuai dengan nilai-nilai Pancasila. Lebih dari itu, mata pelajaran PPKn menuntut siswa untuk menerapkan nilai-nilai pancasila dalam membentuk nilai-nilai moral yang mengarah kepada karakter bangsa (Astawa, Putra, \& Abadi, 2020). Hal tersebut didukung oleh pernyataan dari (Sariani, Dantes, \& Parmiti, 2016) menyatakan bahwa tujuan akhir dari mata pelajaran PPKn adalah bagaimana guru mampu menanamkan nilai-nilai karakter serta mampu menjadikan peserta didik sebagai warga Negara yang baik. Dengan begitu dapat disimpulkan bahwa muatan dari materi PPKn adalah untuk menjadikan warga Negara berkarakter sesuai dengan nilai-nilai Pancasila dan nilai-nilai leluhur Bangsa Indonesia. Penguatan penddikan karakter merupakan modal utama dalam membangun kemajuan bangsa.

Menurut Perpres No. 87 Tahun 2017, tentang Penguatan Pendidikan Karakter (PPK) menyatakan penguatan pendidikan Karakter dilaksanakan dengan mengamalkan nilai-nilai Pancasila dalam pendidikan karakter terutama meliputi nilai-nilai religius, jujur, toleran, disiplin, bekerja keras, kreatif, mandiri, demokratis, rasa ingin tahu, semangat kebangsaan, cinta tanah air, menghargai prestasi, komunikatif, cinta damai, gemar membaca, peduli lingkungan, peduli sosial, dan bertanggungiawab (Widodo, 2017). Delapan belas nilai tersebut dapat dikristalisasi menjadi lima nilai utama karakter yaitu: (1) religius, (2) nasionalis, (3) mandiri, (4) integritas, dan (5) gotong royong, berikut penjelasan kelima karakter utama:

1. Religius, mencerminkan keberimanan kepada Tuhan Yang Maha Esa.

2. Nasionalis, menempatkan kepentingan bangsa dan negara di atas kepentingan diri dan kelompoknya.

3. Mandiri, tidak bergantung kepada orang lain dan mempergunakan tenaga, pikiran, waktu untuk merealisasikan harapan, mimpi, dan cita-cita.

4. Gotong royong, mencerminkan tindakan menghargai semangat kerja sama dan bahu membahu menyelesaikan persoalan bersama.

5. Integritas, upaya menjadikan dirinya sebagai orang yang selalu dapat dipercaya dalam perkataan, tindakan, dan pekerjaan. 
Fajar, Framz, Efektifitas Model Pembelajaran PBL

Penanaman nilai karakter dalam pembelajaran adalah menjadi hal yang utama dalam kemajuan pendidikan karena salah satu keberhasilan dari pendidikan tidak hanya menilai seberapa bisa menjawab pertanyaan dalam soal ulangan melainkan seberapa bisa siswa berperilaku dan menerapkan nilai-nilai karakter dalam kehidupannya. Secara hakikat, output dari pendidikan tidak hanya mengedepankan nilai pengetahuan semata melainkan juga menciptakan nilai-nilai karakter. Oleh sebab itu, guru perlu mengedapankan nilai-nilai karakter dalam proses pembelajaran di sekolah. Tentunya penanaman nilai karakter harus menitikberatkan pada ranah afektif maupun sikap kepada anak didik meskipun telah termuat dalam mata pelajaran PPKn (Suganti, 2017). Hal tersebut sejalan sependapat dengan penelitian yang dilakukan oleh (Rachmadyanti, 2017) menyatakan pendidikan karakter memiliki misi penting dalam menciptakan siswa yang tidak hanya pandai secara kognitif, namun juga berbudi pekerti yang luhur. Hal tersebut sejalan dengan kebutuhan abad 21, dimana para guru tidak hanya dituntut untuk mengajar saja melainkan membentuk karakter positif agar mereka menjadi generasi mas. Hal tersebut sesuai dengan pendapat (Wening, 2012) yang mengemukakan bahwa pembangunan karakter yang berdasar pada nilai-nilai moral kemanusiaan sangan diperlukan oleh individu atau masyarakat melalui adanya proses nilai. Sehingga, untuk mempersiapkan pembelajaran yang efisien dalam melakukan penguatan karakter dibutuhkan perangkat yang valid serta praktis dan efisien. Adapun tujuan dari penelitian ini adalah untuk menghasilkan perangkat pembelajaran dengan model problem based learning yang layak, praktis, dan efektif untuk melakukan penguatan karakter pada KI 2.

\section{METODE}

Penelitian ini merupakan penelitian pengembangan (Research \& Development) dan eksperimen dalam bidang pendidikan. Penelitian ini disebut dengan penelitian pengembangan karena fokus pengembangan perangkat pembelajaran melalui model problem based learning dalam penguatan karakter KI 2 kelas IV. Produk yang akan dihasilkan dalam penelitian pengembangan ini adalah Perangkat pembelajaran yang terdiri dari Rencana Pelaksanaan Pembelajaran (RPP), LKS, dan Jurnal Sikap pada KI 2. Prosedur pengembangan perangkat pembelajaran dalam penelitian ini menggunakan model 4D. Prosedur penelitian ini terdiri atas empat tahap, yaitu pendefinisian (define), perencanaan (design), pengembangan (develop) dan pendesiminasian (dissemenation) (Ernawati, 2014). Akan tetapi dalam tahap pendesiminasian (dissemenation) dilaksanakan secara terbatas. Penelitian ini dilaksanakan di Sekolah Dasar Sang Timur Sumenep tahun ajaran 2020/2021. Subjek penelitian ini adalah siswa kelas IV SDK Sang Timur. Subjek penelitian ini sebanyak 12 siswa.

Selanjutnya, rancangan desain uji coba perangkat ini menggunakan penelitian the one group Pretest-Posttest Design 
Fajar, Framz, Efektifitas Model Pembelajaran PBL

Tabel 1: Desain Ujicoba One Group Pretest-Posttest design

\begin{tabular}{|c|c|c|}
\hline Pretest & Treatment & Posttest \\
\hline O1 & $\mathrm{X}$ & $\mathrm{O} 2$ \\
\hline
\end{tabular}

(Sumber: Sugiyono dalam (Akhir, 2011))

Sementara itu, jenis data yang akan diperoleh dalam penelitian ini adalah: (1). Penilaian kelayakan produk perangkat pembelajaran yang meliputi RPP, LKS dan Jurnal Sikap Penguatan Karakter Utama KI 2. (2). Data respon peserta didik terhadap pembelajaran problem based learning. (3). Data analisis aktivitas siswa selama proses pembelajaran. (4). Data analisis jurnal sikap karakter utama pada KI 2. Selanjutnya teknik analisis data dalam penelitian ini meliputi (1). Analisis penilaian kelayakan problem based learning yang dikembangkan oleh dosen dan guru kelas IV. (2). Analisis data respon peserta didik terhadap pembelajaran problem based learning. (3) Analisis aktivitas siswa selama proses pembelajaran. (4). Analisis jurnal sikap karakter utama pada KI 2. (5) analisis kemampuan pemecahan masalah

\section{HASIL}

\section{Hasil Validasi Perangkat}

Hasil pengembangan perangkat pembelajaran model probem based learning yang dikembangkan valid untuk digunakan dalam pembelajaran PPKN dalam melakukan penguatan karakter KI 2

Tabel 2: Hasil Validasi perangkat pembelajaran model promblem based learning

\begin{tabular}{|l|l|c|c|}
\hline No & Jenis Perangkat & $\begin{array}{c}\text { Nilai } \\
\text { rata- rata }\end{array}$ & Kategori \\
\hline 1 & RPP & 3,7 & Baik \\
\hline 2 & LKS & 3,6 & Baik \\
\hline 3 & Jurnal sikap & 3,6 & Valid \\
\hline
\end{tabular}

\section{Hasil Keterlaksanaan RPP}

Semua tahap-tahap kegiatan yang ada di dalam RPP di kelas telah terlaksana dan secara rata-rata keseluruhan skor keterlaksanaannya adalah 3.7 dengan kategori baik. dan rata-rata reliabilitas $97 \%$.

\section{Hasil Analisis Aktivitas Siswa Selama Pembelajaran}

Setiap aktivitas siswa dicatat, berikut hasil rekapitulasi aktivitas siswa selama proses pembelajaran sebagai berikut:

TABEL3: Hasil analisis aktivitas siswa

\begin{tabular}{|c|c|c|c|c|c|c|c|c|}
\hline \multirow{3}{*}{ No } & \multirow{3}{*}{$\begin{array}{l}\text { Aktivitas siswa } \\
\text { yang diamati }\end{array}$} & \multirow{3}{*}{$\begin{array}{l}\text { Butir } \\
\text { Sikap }\end{array}$} & \multicolumn{6}{|c|}{ Pertemuan } \\
\hline & & & \multicolumn{3}{|c|}{ Pertemuan I } & \multicolumn{3}{|c|}{ Pertemuan II } \\
\hline & & & $\begin{array}{c}\mathrm{NP} \\
\mathrm{I}\end{array}$ & $\begin{array}{c}\text { NP } \\
\text { II }\end{array}$ & $\%$ & $\begin{array}{c}\mathrm{NP} \\
\mathrm{I}\end{array}$ & $\begin{array}{c}\mathrm{NP} \\
\text { II }\end{array}$ & $\%$ \\
\hline 1 & Membuat laporan berdasarkan & Jujur & 87.5 & 90 & 88.75 & 90 & 90 & 90 \\
\hline
\end{tabular}


Fajar, Framz, Efektifitas Model Pembelajaran PBL

\begin{tabular}{|c|l|c|c|c|c|c|c|c|}
\hline \hline & data & & & & & & & \\
\hline 2 & $\begin{array}{l}\text { Berani bependapat, bertanya dan } \\
\text { menjawab }\end{array}$ & $\begin{array}{c}\text { Percaya } \\
\text { diri }\end{array}$ & 85 & 85 & 85 & 90 & 95 & 92.5 \\
\hline 3 & Menghargai pendapat orang lain & Santun & 85 & 85 & 85 & 90 & 90 & 90 \\
\hline 4 & $\begin{array}{l}\text { Mengumpulkan tugas tepat } \\
\text { waktu }\end{array}$ & Disiplin & 90 & 85 & 87.5 & 90 & 90 & 90 \\
\hline \multicolumn{1}{|c|}{ Rata-rata } & \multicolumn{3}{|c|}{$86,56 \%$} & \multicolumn{3}{|c|}{$90,62 \%$} \\
\hline
\end{tabular}

\section{Hasil Analisis Respon Siswa Terhadap Pembelajaran}

Angket respon ini diberikan kepada siswa setelah mengikuti kegiatan pembelajaran. Adapun hasil rekapitulasi respon siswa terbagi dalam dua pernyataan yaitu favorable unfavorable. Berdasarkan hasil respon siswa dari jawaban angket yang disebar terhadap 12 orang siswa dalam ujicoba menunjukkan 91,25\% dari kategori respon favorable dan $8.75 \%$ dari kategori respon unfavorable.

\section{Hasil analisis Jurnal Sikap Karakter Utama KI 2}

Hasil analisi Tes afektif dalam hal ini mengarah kepada penguatan karakter. Selama proses pembelajaran siswa diarahkan melaksanakan aktivitas pembelajaran melalui model problem based learning dalam penguatan karakter pada KI 2 adapun hasil tes belajar afektif yang diperoleh melalui jurnal sikap selama proses pembelajaran sebagai berikut

TABEL. 4 Hasil analisis karakter utama

\begin{tabular}{|c|c|c|c|c|}
\hline No & $\begin{array}{l}\text { Indikator } \\
\text { Karakter utama }\end{array}$ & Subindikator & Capaian & Kategori \\
\hline 1 & Nasionalisme & $\begin{array}{l}\text { Menerima berbagai gagasan dari } \\
\text { teman lain }\end{array}$ & $87 \%$ & Baik \\
\hline 2 & Kerjasama & $\begin{array}{l}\text { Melakukan kolabarasi antar teman } \\
\text { dalam memecahkan masalah }\end{array}$ & $85 \%$ & Baik \\
\hline 3 & Gotong royong & $\begin{array}{l}\text { Mencari solusi dalam pemecahan } \\
\text { masalah }\end{array}$ & $90 \%$ & Sangat Baik \\
\hline 4 & Integritas & $\begin{array}{l}\text { Menyajikan informasi sesuai hasil } \\
\text { diskusi }\end{array}$ & $95 \%$ & Sangat Baik \\
\hline & Rata-rata & & $89.25 \%$ & Baik \\
\hline
\end{tabular}

\section{Hasil analisis pretest dan posttest soal pemecahan masalah melalui problem} based learning

TABEL. 5 Hasil analisis Pemecahan Masalah

\begin{tabular}{|l|l|c|c|}
\hline No & Nama & Hasil Pretest Pemecahan Masalah & Hasil Posttest Pemcahan Masalah \\
\hline 1 & Vn & 80 & 95 \\
\hline 2 & JJ & 60 & 80 \\
\hline 3 & Cls & 80 & 95 \\
\hline 4 & Jv & 65 & 85 \\
\hline 5 & Ln & 65 & 83 \\
\hline 6 & Fb & 70 & 90 \\
\hline 7 & Mtw & 60 & 83 \\
\hline 8 & Jyln & 55 & 80 \\
\hline 9 & Rh & 70 & 80 \\
\hline 10 & FL & 65 & 85 \\
\hline 11 & Nc & 65 & 88 \\
\hline 12 & VV & 60 & 90 \\
\hline
\end{tabular}


Fajar, Framz, Efektifitas Model Pembelajaran PBL

\begin{tabular}{|c|c|c}
\hline Rata-rata & $66,25 \%$ & $86 \%$ \\
\hline
\end{tabular}

\section{PEMBAHASAN}

Hasil kelayakan perangkat ditentukan oleh dua validator. Adapun validator yang dipilih dalam penelitian ini adalah guru kelas IV dan dan dari salah satu dosen PGSD STKIP PGRI Sumenep. Validasi perangkat ini dimaksudkan untuk mengetahui kelayakan perangkat yang akan digunakan dalam penelitian. Untuk kelayakan perangkat yang digunakan memperoleh nilai rata-rata 3.7 kategori baik untuk RPP, 3.6 ketegori baik untuk LKS, dan jurnal sikap penguatan karakter utama KI 2 memperoleh nilai ratarata 3.6 kategori valid.

Selanjutnya keterlaksanaan rencana pelaksanaan pembelajaran dilaksanakan penilaiain dan pengamatan setiap kali pertemuan. Secara garis besar keterlaksanaan RPP meliputi pendahuluan, inti dan penutup serta pengelolahan kelas. Secara esensi keterlaksanaan RPP yang baik adalah dimana guru mampu mengarahkan siswanya untuk belajar melalui model problem based learning sesuai dengan tahapan. Adapun hasil yang diperoleh dalam keterlaksanaan RPP ini adalah 3.7 dengan kategori baik. dan rata-rata reliabilitas $97 \%$.

Sedangkan untuk analisis siswa adalah berdasarkan pada karakter utama dalam KI 2. Analisis aktivitas siswa dilakukan oleh dua orang pengamat setiap pertemuan. Hasil aktivitas siswa menunjukkan $86.56 \%$ pada pertemuan 1 \& dan $90.62 \%$ pada pertemuan 2 dengan kategori baik. Adapun analisis aktivitas siswa berdasarkan dari sintak problem based learning dan butir sikap pada KI 2. Sejauh ini proses pembelajaran melalui model problem based learning memang memberikan dampak positif khususnya pada butir sikap percaya diri. Dimana para siswa sangat antusias untuk menjawab, bertanya dan tentang materi yang disampaikan. Selain itu, hasil aktivitas siswa tersebut sejalan dengan hasil analisis respon siswa terhadap model pembelajaran problem based learning dalam penguatan karakter KI 2. Hasil respon siswa menunjukkan $91.25 \%$ setuju, senang dan efektif terhadap model pembelajaran problem based learnig pada mata pelajaran PPKn, $8.75 \%$ tidak setuju, tidak terbiasa dengan pembelajaran model tersebut.

Kemudian, hasil analisis jurnal sikap pada penguatan karakter KI 2 juga menunjukkan hasil yang sangat signifikan dimana hasil yang diperoleh dari subindikator karakter utama menunjukkan rata-rata yang diperoleh adalah $89.25 \%$ ketegori baik. Secara keseluruhan tahapan dalam pembelajaran problem based learning sudah baik dalam penguatan karakter KI 2. Selain itu, hasil analisis jurnal sikap juga selaras dengan hasil tes pemecahan masalah yang dilakukan oleh peneliti. Dimana pada hasil pretest untuk soal pemecahan masalah mendapatkan nilai rata-rata $66.25 \%$. setelah mendapatkan perlakuan melalui model pembelajaran problem based learning mendapatkan nilai rata-rata pada hasil posttetst adalah $86.58 \%$. Hasil tersebut sejalan dengan hasil penelitian yang dilakukan oleh (Nafiah \& Suyanto, 2014) menyatakan penerapan PBL dapat meningkatkan hasil belajar siswa sebesar 31,03\%, dan (d) Hasil 
Fajar, Framz, Efektifitas Model Pembelajaran PBL

belajar siswa setelah penerapan PBL yakni jumlah siswa yang mencapai KKM sebanyak 29 siswa (100\%). Tidak hanya itu, penelitian yang dilakukan oleh (Susanto, 2017) menyatakan bahwa implikasi perangkat pembelajaran problem based learning yang valid, praktis dan efektif dapat meningkatkan kemampuan berpikir kritis. Tidak hanya pada pembelajaran eksak yang memberikan pengaruh signifikan, ternyata proses pembelajaran problem based learning juga memberikan hasil yang signifikan pada mata pelajaran PPKn. Hal tersebut sejalan dengan hasil penelitian yang dilakukan oleh (Sukaptiyah, 2015) melalui penelitian tindakan kelas menunjukkan bahwa melalui metode Problem Based Learning dapat meningkatkan prestasi hasil belajar PKn pada siswa Kelas VI SD Negeri 1 Mongkrong, Wonosegoro Semester I tahun pelajaran 2014/2015. Proses belajar PKn materi Proses Perumusan Pancasila dari siklus I ke siklus II terdapat peningkatan: hasil belajar siswa dari siklus I ke siklus II mengalami peningkatan

Dengan begitu hasil pengembangan perangkat melalui problem based learning sejalan dengan hasil penelitian sebelumnya dimana secara lebih khusus peneliti menjabarkan bahwa (1) Perangkat pembelajaran PPKn berbasis problem based learning dalam penguatan karakter KI 2 telah memenuhi syarat kevalidan. syarat tersebut mencakup antara lain. (a) Perangkat pembelajaran PPKn berbasis problem based learning dalam penguatan karakter KI 2 telah memenuhi syarat kevalidan ditinjau dari validitas konten dan konstruk (b) Perangkat pembelajaran PPKn berbasis problem based learning dalam penguatan karakter KI 2 telah memenuhi syarat kevalidan ditinjau dari keterbacaan dengan nilai rata-rata 3.7 kategori baik untuk RPP, 3.6 ketegori baik untuk LKS, dan jurnal sikap penguatan karakter utama KI 2 memperoleh nilai rata-rata 3.6 kategori valid. (2) Perangkat pembelajaran PPKn berbasis problem based learning dalam penguatan karakter KI 2 telah memenuhi syarat kepraktisan. Syarat tersebut mencakup Perangkat pembelajaran PPKn berbasis problem based learning dalam penguatan karakter KI 2 telah memenuhi syarat kepraktisan ditinjau dari keterlaksanaan pembelajaran dengan perolehan hasil 3.7 dengan kategori baik. dan rata-rata reliabilitas 97\%. (3) Perangkat pembelajaran PPKn berbasis problem based learning dalam penguatan karakter KI 2 telah memenuhi syarat keefektifan. Syarat tersebut mencakup antara lain. (a) Perangkat pembelajaran PPKn berbasis problem based learning dalam penguatan karakter KI 2 telah memenuhi syarat keefektifan ditinjau dari peningkatan hasil pemecahan soal melalui problem based learning dengan perolehan hasil pretest $66.25 \%$ dan posttest $86 \%$. (b) Perangkat pembelajaran PPKn berbasis problem based learning dalam penguatan karakter KI 2 telah memenuhi syarat keefektifan ditinjau dari peningkatan hasil analisis jurnal sikap KI 2 dengan perolehan nilai rata-rata 89.25 $\%$ ketegori baik. (c) Perangkat pembelajaran PPKn berbasis problem based learning dalam penguatan karakter KI 2 telah memenuhi syarat keefektifan ditinjau dari peningkatan hasil aktivitas siswa menunjukkan $86.56 \%$ pada pertemuan $1 \&$ dan 90.62\% pada pertemuan 2 dengan kategori sangat baik 
Fajar, Framz, Efektifitas Model Pembelajaran PBL

\section{SIMPULAN}

Berdasarkan analisis, pembahasan hasil, dan temuan penelitian, maka dapat disimpulkan bahwa pengembangan perangkat pembelajaran dengan model problem based learning dalam penguatan karakter pada mata pelajaran PPKn di sekolah dasar SDK Sang timur pada materi keberagaman umat beragama telah memenuhi syarat dimana (1) Perangkat pembelajaran PPKn berbasis problem based learning dalam penguatan karakter KI 2 telah memenuhi syarat kevalidan. (2) Perangkat pembelajaran PPKn berbasis problem based learning dalam penguatan karakter KI 2 telah memenuhi syarat kepraktisan. Syarat tersebut mencakup Perangkat pembelajaran PPKn berbasis problem based learning dalam penguatan karakter KI 2 telah memenuhi syarat kepraktisan ditinjau dari keterlaksanaan pembelajaran (3) Perangkat pembelajaran PPKn berbasis problem based learning dalam penguatan karakter KI 2 telah memenuhi syarat keefektifan.

\section{UCAPAN TERIMA KASIH}

Dalam hal ini, peneliti menyampaikan ucapan terima kasih kepada Ketua STKIP PGRI Sumenep dan Ketua LPPM STKIP PGRI Sumenep yang telah meluangkan waktu dan tenaga dalam membimbing penelitian ini sehingga terselesaikan tepat waktu. Ucapan terimakasih juga kami sampaikan kepada Kepala Sekolah SDK Sang Timur yang telah memberi ruang dan waktu untuk melaksanakan penelitian dan pengembangan perangkat pembelajaran. Siswa -siswi kelas IV di SDK Sang Timur yang turut mensukseskan penelitian ini. Semua pihak yang terlibat dan tidak bias kami sebutkan satu persatu. Semoga Allah SWT membalas kebaikan dan usaha kalian.

\section{DAFTAR RUJUKAN}

Akhir, M. (2011). Penerapan Strategi Belajar Reciprocal Teaching terhadap Kemampuan Membaca pada siswa. Indonesian Journal of Primary Education, $1(2), 30-38$.

Astawa, I. W. W., Putra, M., \& Abadi, I. . G. S. (2020). Pembelajaran PPKn dengan Model VCT Bermuatan Nilai KarakterMeningkatkan Kompetensi Pengetahuan Siswa. Jurnal Pedagogi Dan Pembelajaran, 3(2), 199-210.

Budiarti, I., \& Airlanda, G. S. (2019). Penerapan Model Problem Based Learning berbasis kearifan lokal untuk Meningkatkan Kemampuan Berpikir Kritis. Jurnal Riset Teknologi Dan Inovasi Pendidikan, 2(1), 167-183.

Ernawati. (2014). Pengembangan Perangkat Pembelajaran Berdasarkan Model 4-D pada 
Fajar, Framz, Efektifitas Model Pembelajaran PBL

Materi Getaran Gelombang dan Bunyi dalam meningkatkan pemahaman konsep siswa SMP 6 Palu. Jurnal Sains Dan Teknologi Tadulako, 3(1), 62-71.

Hamburg, I., \& Vladut, G. (2016). PBL - Problem Based Learning for Companies and Clusters. Transportation Research Procedia 18, ) 419 - 425. https://doi.org/10.1016/j.trpro.2016.12.055

Nafiah, Y. N., \& Suyanto, W. (2014). Penerapan Model Problem-Based Learning Untuk Meningkatkan Keterampilan Berpikir Kritis Dan Hasil Belajar Siswa. Jurnal Pendidikan Vokasi, 4(1).

Prasasti, P. A. T. (2015). Efektivitas Model Problem Based Learning (PBL) disertai FishboneDiagram (FB) untuk memberdayakan kemampuan menganalisis. Premiere Educandum, 5(2), 223-238.

Rachmadyanti, P. (2017). Penguatan Pendidikan Karakter Bagi Siswa Sekolah Dasar Melalui Kearifan Lokal. JPSD, 3(2).

Sariani, N. K. D., Dantes, N., \& Parmiti, D. P. (2016). Pengaruh Model Pembelajaran Value Clarification Technique ( Vct ) Terhadap Sikap Sosial Dan Hasil Belajar. EJurnal PGSD Universitas Pendidikan Ganesha, 4(1), 1-10.

Soraya, D., Jampel, I. N., \& Diputra, K. S. (2018). Pengaruh Mode Pembelajaran Problem Based Learning (PBL) Berbasis Kearifan Lokal Terhadap Sikap Sosial dan Berpikir Kritis pada Mata Pelajaran Matematika. TSCJ, 1(2).

Suganti, S. (2017). Penerapan Model Pembelajaran Value Clarification Technique Permainan Untuk Meningkatkan Hasil Belajar Pendidikan Kewarganegaraan. Jurnal Pendidikan Ilmu-Ilmu Sosial, 9(2), 255-262.

Sukaptiyah, S. (2015). Peningkatan Hasil Belajar Pkn Melalui Model Problem Based Learning Pada Siswa Kelas VI SD Negeri 1 Mongkrong Wonosegoro. Scholaria, 5(1), 114-121.

Sumartini, T. S. (2016). Peningkatan Kemampuan Pemecahan Masalah Matematis Siswa melalui Pembelajaran Berbasis Masalah. Jurnal Musharafa, 5(2).

Susanto, S. (2017). Pengembangan Perangkat Pembelajaran IPA dengan Model Pembelajaran Problem Based Learning untuk Meningkatkan Kemampuan Berpikir Kritis Siswa Kelas IV Sekolah Dasar. Jurnal Pendidikan Dasar Nusantara, 3(1).

Tilaar, H. A. R. (2012). Pengembangan Kreativitas dan Entrepreneurship. Jakarta: PT Kompas Media Nusantara.

Wahana, P., \& Mayasari, E. D. (2017). Pengaruh Penerapan Model Pembelajaran Inovatif Pada Mata pelajaran PPKn Terhadap Sikap Siswa Sd Akan Nilai-Nilai Terkait. Jurnal Penelitian.

Wallden, S., \& Makinen, E. (2013). Educational Data Mining and Problem Based Learning. University of Tampere, School of Information Sciences.

Wening, S. (2012). Pembentukan Karakter Bangsa Melalui Pendidikan Nilai. Jurnal Pendidikan Karakter, 2(1), 55-66.

Widodo, J. Peraturan Presiden Nomor 87 Tahun 2017 tentang Penguatan Pendidikan Karakter. , Pub. L. No. 87 (2017).

Winataputra, U. S. D. (2011). Materi dan Pembelajaran IPS SD. Jakarta: Universitas Terbuka. 